\title{
BNIP3 Gene
}

National Cancer Institute

\section{Source}

National Cancer Institute. BNIP3 Gene. NCI Thesaurus. Code C120108.

This gene plays a role in the stimulation of both apoptosis and autophagy. 